\title{
Persepsi Peternak tentang Penerapan Inseminasi Buatan di Tiga Sentra Sapi Potong di Indonesia
}

\section{The Perception of the Slaughter Cattle's Farmers on Implementation of Artificial Insemination in Three Central Areas of Slaughter Cattle in Indonesia}

\author{
Mursyid Ma'sum ${ }^{1}$, Aida Vitayala S. Hubeis ${ }^{2}$, \\ Amiruddin Saleh ${ }^{2}$, Budi Suharjo ${ }^{2}$ \\ ${ }^{1}$ Kementerian Pertanian, Jakarta \\ ${ }^{2}$ Institut Pertanian Bogor, Jawa Barat
}

\begin{abstract}
The general objective of the research is to describe and analyze implementation of adopted artificial insemination (AI) innovation on slaughter cattle's farmers. Specifically, is to describe and analyze the perception of slaughter cattle's farmers on AI in the three locations of research. Locations of the research are Kecamatan Geger Kabupaten Bangkalan and Kecamatan Mantup Kabupaten Lamongan in East Java Province and Kecamatan Penebel Kabupaten Tabanan in Bali Province. This research was designed as a correlation descriptive survey by both quantitative and qualitative approach. The number of sample is 240 respondents -who is the acceptors of AI- and by approach of stratified random sampling method. Data collection was completed with questionnaires, interview and field observation. Kruskal-Wallis Test and U Mann-Whitney Test were applied to analyze the data sample. The result of the research showed that the perception of the farmers on most of AI's aspects are significantly different among locations of the research, with the exception of the phenotipe (physical appearance) of breed cattle and the artificial insemination services by inseminators. To be suggested that socialization or extension on AI should be conducted by different approaches to fit the characteristic of internal and external and AI's perception of the farmers.
\end{abstract}

Keywords: Perception, artificial insemination

Abstrak

Tujuan penelitian secara umum adalah menggambarkan dan menganalisis tingkat penerapan dan adopsi inovasi inseminasi buatan (IB). Secara khusus penelitian ini bertujuan untuk menggambarkan dan menganalisis persepsi peternak tentang IB di tiga lokasi sentra sapi potong di Indonesia. Penelitian ini telah dilaksanakan di Kecamatan Geger Kabupaten Bangkalan dan Kecamatan Mantup Kabupaten Lamongan Jawa Timur serta Kecamatan Penebel Kabupaten Tabanan Bali, yang melibatkan 240 responden. Kruskal-Wallis Test dan U MannWhitney Test digunakan untuk menganalisis perbedaan persepsi peternak antar lokasi penelitian. Hasil penelitian menunjukkan bahwa terdapat perbedaan yang nyata persepsi peternak tentang IB antar lokasi penelitian, kecuali persepsi terhadap aspek tanda fisik sapi bibit dan pelayanan inseminator. Disarankan, dalam memberikan penyuluhan tentang IB agar menggunakan pendekatan yang berbeda sesuai dengan karakteristik internal dan eksternal peternak sapi potong dan persepsinya tentang IB.

Kata kunci: Persepsi, inseminasi buatan

\section{Pendahuluan}

Teknologi IB diperkenalkan di Indonesia pada tahun lima-puluhan. Kemudian mulai dilakukan ujicoba dan disosialisasikan ke daerah-daerah pada tahun 1969, namun kebijakan penerapan IB oleh Pemerintah c.q Direktorat Jenderal Peternakan baru dimulai tahun 1976 bersamaan dengan diresmikannya sentra inseminasi buatan Lembang. Kebijakan

\footnotetext{
${ }^{1}$ Korespondensi penulis. Telp: 081519984288

E-mail: murma_sang@yahoo.com
}

penerapan IB saat itu ditujukan untuk meningkatkan produksi dan produktivitas sapi perah dan sapi potong. Untuk sapi perah ditempuh melalui grading up dengan mendatangkan pejantan unggul (proven bull) dari luar negeri, sedangkan untuk sapi potong, melalui grading up ternak asli seperti sapi Bali dan Ongole dan melalui persilangan dengan sapi potong dari luar negeri (BIB Lembang 2001).

Inseminasi Buatan sebagai teknologi reproduksi dalam penerapannya merupakan salah satu instrumen dalam mengimplementasi- 
kan kebijakan di bidang perbibitan. Menurut Gordon (2004), bahwa IB sebagai teknologi reproduksi, tidak diragukan lagi adalah cara yang paling penting yang diterapkan pada sapi selama abad 20, karena IB secara relatif, lebih murah dan mudah untuk diterapkan. Menurut Skjervold (1982), selama dua dekade terakhir IB telah menjadi cara perkawinan yang paling penting, dan lebih jauh IB telah memberikan dimensi baru pada kegiatan pembibitan ternak sapi. Inseminasi Buatan, secara umum bertujuan untuk (1) meningkatkan mutu genetik ternak hasil IB; (2) mempercepat penyebaran gen-gen unggul pada sapi keturunannya; dan (3) meningkatkan efisiensi penggunaan pejantan unggul (Foote 1981 dan Gordon 2004). Implikasi dari penerapan IB ini adalah meningkatnya produksi dan produktivitas ternak turunannya, sekaligus dapat meningkatkan populasi. Setelah hampir empat dekade sejak IB diperkenalkan, fenomena respons masyarakat terhadap teknologi IB ini bervariasi. Fenomena tersebut secara umum dapat dikategorikan menjadi empat macam: (1) menjadi IB minded; (2) menerima; (3) masih mencoba-coba; dan (4) menolak.

Dari aspek penyuluhan, teknologi IB telah menggantikan cara perkawinan sapi yang selama ini dilakukan secara turun-temurun, yaitu kawin secara alami. Aspek lain, pemeliharaan sapi potong dan cara perkawinan telah menjadi bagian dari sistem sosial dan budaya masyarakat yang bersangkutan. Oleh karena itu, proses perubahan perilaku peternak sapi potong dalam merespons IB sebagai suatu inovasi teknologi reproduksi bukanlah hal yang sederhana. Hal ini dipengaruhi oleh banyak faktor dan prosesnya membutuhkan waktu. Beberapa faktor yang mempengaruhi respons peternak dengan diperkenalkannya suatu inovasi, secara umum dipengaruhi oleh masalah teknis, sosial, ekonomi dan budaya. Menurut Lionberger dan Gwin (1982) hal tersebut sebagian dipengaruhi oleh (1) faktor individu, (2) situasi dan (3) sifat dari inovasi tersebut. Lebih jauh dikatakan, bahwa respons terhadap suatu inovasi sangat berbeda antara orang-perorang dan masyarakat yang satu dengan yang lain, serta peubah-peubahnya juga berbeda. Hal ini mengindikasikan diperlukan- nya pendekatan yang berbeda dalam memberikan penyuluhan IB kepada masyarakat.

Sejauh ini, menurut van den Ban dan Hawkins (1999), dalam kebanyakan penelitian tentang difusi inovasi, sedikit sekali perhatian diberikan terhadap perubahan yang besar dalam struktur sosial atau cara hidup masyarakat. Perubahan kelembagaan dan masyarakat jarang diteliti, padahal perubahan sosial yang demikian sangat penting, khususnya di kalangan masyarakat pedesaan.

Inovasi menurut Rogers (2003) adalah suatu gagasan, tindakan atau obyek yang dianggap baru oleh suatu individu atau beberapa individu. Inseminasi Buatan sebagai salah satu teknologi reproduksi, masuk pada kategori "technological innovation." Menurut Rogers (2003) setiap teknologi terdiri dua komponen, yaitu (1) suatu perangkat keras (hardware) yang terdiri dari peralatan dan (2) suatu perangkat lunak (software) yang merupakan informasi ataupun pengetahuan dasar dari peralatan tersebut dan cara penggunaannya. Karakteristik inovasi, sebagaimana mereka persepsikan, akan menjelaskan perbedaan kecepatan proses adopsi. Beberapa hal yang terkait dengan ini adalah (1) kelebihan/ keutamaan relatif (relative advantages), (2) kesesuaian (compatibility), (3) derajat kerumitan (complexity), (4) dapat dicoba (trialability) dan (5) dapat dilihat (observability) (Nasution 2002).

Adopsi adalah suatu keputusan untuk menerima sepenuhnya suatu inovasi (gagasan, tindakan dan/atau obyek) sebagai pilihan terbaik yang tersedia untuk bertindak atau melakukan sesuatu (Rogers 2003). Menurut Lionberger dan Gwin (1982), sebelum sampai pada adopsi, proses yang dilalui oleh individu adalah kepedulian, ketertarikan, penilaian, mencoba dan menerima (awareness, interest, evaluation, trial dan adoption). Ada banyak variabel yang mempengaruhi seseorang dalam mengambil keputusan inovasi mulai dari "pengenalan" sampai dengan mengambil "keputusan" apakah menerima inovasi tersebut ataupun menolaknya. Begitu juga setelah mengambil keputusan, diperlukan waktu untuk "konfirmasi" apakah akan diteruskan menerima ataupun berhenti. Bagi yang menolak, 
Jurnal Penyuluhan, Maret 2012 Vol. 8 No. 1

mungkin akan terus menolak ataupun pada akhirnya menerima setelah melihat banyak bukti yang berhasil (Rogers \& Shomakers 1995). Setidak-tidaknya ada beberapa faktor yang berpengaruh terhadap tingkat maupun kecepatan proses adopsi inovasi, yaitu latar belakang peternak, baik yang berkaitan dengan individu (karakteristik internal) maupun sistem sosial (karakteristik eksternal), proses komunikasi dan sifat dari inovasinya serta dimensi waktu.

Masalah penelitian yang menjadi fokus amatan adalah bagaimanakah persepsi peternak sapi potong terhadap IB? Secara umum penelitian ini bertujuan untuk mengetahui tingkat kecepatan adopsi inovasi IB. Secara khusus adalah untuk mengetahui (1) karakte- ristik internal dan eksternal peternak sapi potong dan (2) persepsi peternak sapi potong terhadap IB.

\section{Metode Penelitian}

Penelitian ini dirancang sebagai penelitian survai deskriptif korelasional, dengan pendekatan kuantitatif dan kualitatif. Lokasi penelitian adalah Kabupaten Lamongan dan Kabupaten Bangkalan Provinsi Jawa Timur serta Kabupaten Tabanan Provinsi Bali. Tiga kabupaten tersebut merupakan sentra sapi potong di Indonesia yang mewakili masing-masing dua jenis ternak lokal, yaitu sapi PO dan Madura, serta satu ternak asli, yaitu sapi Bali. Di samping itu, tiga lokasi tersebut telah menerapkan IB

Tabel 1. Distribusi indikator karakteristik internal peternak sapi potong

\begin{tabular}{|c|c|c|c|c|c|c|c|c|}
\hline \multirow[b]{2}{*}{ Karakteristik Internal } & \multicolumn{2}{|c|}{ Bangkalan } & \multicolumn{2}{|c|}{ Lamongan } & \multicolumn{2}{|c|}{ Tabanan } & \multicolumn{2}{|c|}{ Total } \\
\hline & $\begin{array}{c}\text { Jml. } \\
\text { (orang) }\end{array}$ & $\begin{array}{c}\text { Persen } \\
(\%)\end{array}$ & $\begin{array}{c}\text { Jml. } \\
\text { (orang) }\end{array}$ & $\begin{array}{c}\text { Persen } \\
(\%)\end{array}$ & $\begin{array}{l}\text { Jml. } \\
\text { (oran) }\end{array}$ & $\begin{array}{c}\text { Persen } \\
(\%)\end{array}$ & $\begin{array}{l}\text { Jml. } \\
\text { (oran) }\end{array}$ & $\begin{array}{c}\text { Persen } \\
(\%)\end{array}$ \\
\hline \multicolumn{9}{|l|}{ Umur peternak (tahun) } \\
\hline - Muda (25-33) & 1 & 1,3 & 8 & 10,0 & 5 & 6,3 & 14 & 5,8 \\
\hline - Dewasa (34-51) & 51 & 63,7 & 57 & 71,3 & 41 & 51,3 & 149 & 62,1 \\
\hline - Tua (52-68) & 28 & 35,0 & 15 & 18,7 & 34 & 42,4 & 77 & 32,1 \\
\hline \multicolumn{9}{|l|}{ Pendidikan peternak } \\
\hline - Rendah (<tamat SD) & 79 & 98,7 & 53 & 66,2 & 45 & 56,2 & 177 & 73,8 \\
\hline - Sedang (tamat SMP/SMA) & 1 & 1,3 & 25 & 31,3 & 33 & 41,3 & 59 & 24,6 \\
\hline - Tinggi (tamat Diploma/PT) & 0 & 0,0 & 2 & 2,5 & 2 & 2,5 & 4 & 1,6 \\
\hline \multicolumn{9}{|c|}{$\begin{array}{l}\text { Pengalaman memelihara sapi potong (tahun) } \\
\text { - Kurang pengalaman }(1-11)\end{array}$} \\
\hline - Pengalaman (12-33) & 9 & 11,3 & 21 & 26,3 & 10 & 12,5 & 40 & 16,7 \\
\hline - Sangat pengalaman (34-55) & 71 & 88,7 & 38 & 47,5 & 40 & 50,0 & 149 & 62,1 \\
\hline & 0 & 0 & 21 & 26,2 & 30 & 37,5 & 51 & 21,2 \\
\hline \multicolumn{9}{|l|}{ Jumlah pemilikan sapi (ST) } \\
\hline - Sedikit $(0,5-1,9)$ & 49 & 61,3 & 29 & 36,2 & 51 & 63,7 & 129 & 53,8 \\
\hline - Sedang $(>1,9-4,9)$ & 31 & 38,7 & 50 & 62,5 & 29 & 36,3 & 110 & 45,8 \\
\hline - Banyak $(>4,9-7,5)$ & 0 & 0,0 & 1 & 1,3 & 0 & 0,0 & 1 & 0,4 \\
\hline \multicolumn{9}{|l|}{ Tujuan pemeliharaan (pendapatan) } \\
\hline - Sampingan $(<30 \%)$ & 68 & 85,1 & 46 & 57,5 & 37 & 46,2 & 151 & 62,9 \\
\hline - Cabang usaha (30-70\%) & 9 & 11,2 & 12 & 15,0 & 31 & 38,8 & 52 & 21,7 \\
\hline - Usaha pokok $(>70 \%)$ & 3 & 3,7 & 22 & 27,5 & 12 & 15,0 & 37 & 15,4 \\
\hline \multicolumn{9}{|l|}{ Motivasi menggunakan IB } \\
\hline - Faktor eksternal (ekstrinsik) & 47 & 58,7 & 42 & 52,5 & 56 & 70,0 & 145 & 60,4 \\
\hline - Kesadaran sendiri (intrinsik) & 33 & 41,3 & 38 & 47,5 & 24 & 30,0 & 95 & 39,6 \\
\hline \multicolumn{9}{|l|}{ Keanggotaan dalam Kelompok IB } \\
\hline - Bukan anggota & 68 & 85,0 & 78 & 97,4 & 80 & 100 & 226 & 94,2 \\
\hline - Anggota/Pengurus & 12 & 15,0 & 2 & 2,6 & 0 & 0,0 & 14 & 5,8 \\
\hline \multicolumn{9}{|l|}{ Tingkat kekosmopolitan (kali/bln) } \\
\hline - Rendah (0-2) & 43 & 53,0 & 34 & 42,4 & 76 & 95,0 & 153 & 63,6 \\
\hline - Sedang (3-8) & 37 & 47,0 & 32 & 40,1 & 4 & 5,0 & 73 & 30,6 \\
\hline - Tinggi (9-12) & 0 & 0,0 & 14 & 17,5 & 0 & 0,0 & 14 & 5,8 \\
\hline \multicolumn{9}{|l|}{ Pendapatan jual sapi (juta rupiah/thn) } \\
\hline - Rendah $(<8,6)$ & 78 & 97,5 & 55 & 68,7 & 65 & 81,3 & 198 & 82,5 \\
\hline - Sedang $(8,6-25,7)$ & 2 & 2,5 & 21 & 26,2 & 15 & 18,7 & 38 & 15,8 \\
\hline - Tinggi (>25,7-42,9) & 0 & 0,0 & 4 & 5,1 & 0 & 0,0 & 4 & 1,7 \\
\hline
\end{tabular}


dalam jangka waktu yang cukup lama.

Kabupaten Lamongan merupakan sentra jenis sapi PO dengan arah perkawinan persilangan;

Kabupaten Bangkalan adalah sentra sapi jenis Madura dengan arah perkawinan sebagian persilangan dan sebagian pemurnian. Sedangkan Kabupaten Tabanan merupakan sentra jenis sapi Bali, dengan arah perkawinan pemurnian. Populasi penelitian ini ialah semua peternak sapi potong akseptor IB di Kecamatan Mantub Kabupaten Lamongan, Kecamatan Geger Kabupaten Bangkalan dan Kecamatan Penebel Kabupaten Tabanan yang berjumlah 3.258 orang. Jumlah sampel 240 peternak dengan masing-masing lokasi 80 peternak. Data primer dikumpulkan dengan cara melakukan wawancara kepada responden dengan berpedoman pada kuesioner yang telah dipersiapkan dan telah diujicobakan sebelumnya dan dari sumber lain. Beberapa uji statistik yang digunakan untuk menganalisis data adalah (1) analisis deskriptif dan (2) analisis Kruskal-Wallis Test dan U Mann-
Whitney Test digunakan untuk menguji perbedaan rataan beberapa sampel.

\section{Hasil dan Pembahasan}

\section{Karakteristik internal peternak sapi potong}

Peubah "karakteristik internal peternak sapi potong" mencakup beberapa indikator sebagaimana dapat dilihat pada Tabel 1 berikut.

Hasil pengujian data sampel menggunakan Kruskal-Wallis Test menunjukkan bahwa secara umum karakteristik internal peternak sapi potong berbeda secara nyata, kecuali motivasi menggunakan IB tidak berbeda secara nyata antar lokasi penelitian.

\section{Karakteristik eksternal peternak sapi potong}

Peubah "karakteristik eksternal peternak sapi potong" terdiri dari beberapa indikator sebagaimana dapat dilihat pada Tabel 2.

Tabel 2. Distribusi indikator karakteristik eksternal peternak sapi potong

\begin{tabular}{|c|c|c|c|c|c|c|c|c|}
\hline \multirow[b]{2}{*}{ Karakteristik Eksternal } & \multicolumn{2}{|c|}{ Bangkalan } & \multicolumn{2}{|c|}{ Lamongan } & \multicolumn{2}{|c|}{ Tabanan } & \multicolumn{2}{|c|}{ Total } \\
\hline & $\begin{array}{c}\text { Jml. } \\
\text { (orang) }\end{array}$ & $\begin{array}{c}\text { Persen } \\
(\%)\end{array}$ & $\begin{array}{c}\text { Jml. } \\
\text { (orang) }\end{array}$ & $\begin{array}{c}\text { Persen } \\
(\%)\end{array}$ & $\begin{array}{c}\text { Jml. } \\
\text { (orang) }\end{array}$ & $\begin{array}{c}\text { Persen } \\
(\%)\end{array}$ & $\begin{array}{c}\text { Jml. } \\
\text { (orang) }\end{array}$ & $\begin{array}{c}\text { Persen } \\
(\%)\end{array}$ \\
\hline \multicolumn{9}{|l|}{ Kelembagaan IB } \\
\hline - Rendah (hanya 1) & 75 & 93,7 & 64 & 80,0 & 67 & 83,7 & 206 & 85,8 \\
\hline - Sedang (ada 2) & 5 & 6,3 & 10 & 12,5 & 13 & 16,3 & 28 & 11,7 \\
\hline - Tinggi (lebih dari 2) & 0 & 0,0 & 6 & 7,5 & 0 & 0,0 & 6 & 2,5 \\
\hline \multicolumn{9}{|l|}{ Keadaan sarana-prasarana IB } \\
\hline - Tidak ada & 22 & 27,5 & 76 & 95,0 & 41 & 51,3 & 139 & 57,9 \\
\hline - Rendah (hanya ada 1) & 52 & 65,0 & 3 & 3,7 & 15 & 18,7 & 70 & 29,2 \\
\hline - Tinggi (lebih dari 2) & 6 & 7,5 & 1 & 1,3 & 24 & 30,0 & 31 & 12,9 \\
\hline \multicolumn{9}{|l|}{ Kepastian pasar sapi } \\
\hline - Rendah (hanya 1 pilihan) & 37 & 46,3 & 79 & 98,7 & 58 & 72,5 & 174 & 72,5 \\
\hline - Sedang (ada 2 pilihan) & 43 & 53,7 & 1 & 1,3 & 22 & 27,5 & 66 & 27,5 \\
\hline \multicolumn{9}{|l|}{ Intensitas penyuluhan (kali/6 bulan) } \\
\hline - Jarang ( $\leq 2$ kali) & 48 & 60,0 & 79 & 98,7 & 51 & 63,7 & 178 & 74,2 \\
\hline - Sering (3-5 kali) & 32 & 40,0 & 0 & 0,0 & 6 & 7,5 & 38 & 15,8 \\
\hline - Sangat sering (6 kali atau lebih) & 0 & 0,0 & 1 & 1,3 & 23 & 28,8 & 24 & 10,0 \\
\hline \multicolumn{9}{|l|}{ Ketersediaan informasi IB } \\
\hline - Sulit (hanya 1) & 14 & 17,5 & 11 & 13,7 & 2 & 2,5 & 27 & 11,2 \\
\hline - Mudah (ada 2) & 43 & 53,7 & 56 & 70,0 & 62 & 77,5 & 161 & 67,1 \\
\hline - Sangat mudah (lebih dari 2) & 23 & 28,8 & 13 & 16,3 & 16 & 20,0 & 52 & 21,7 \\
\hline \multicolumn{9}{|l|}{ Sumber informasi IB (macam) } \\
\hline - Rendah (hanya 1) & 29 & 36,2 & 26 & 32,5 & 15 & 18,8 & 70 & 29,2 \\
\hline - Sedang (ada 2) & 48 & 60,0 & 42 & 52,5 & 48 & 60,0 & 138 & 57,5 \\
\hline - Tinggi (lebih dari 2) & 3 & 3,8 & 12 & 15,0 & 17 & 21,2 & 32 & 13,3 \\
\hline
\end{tabular}




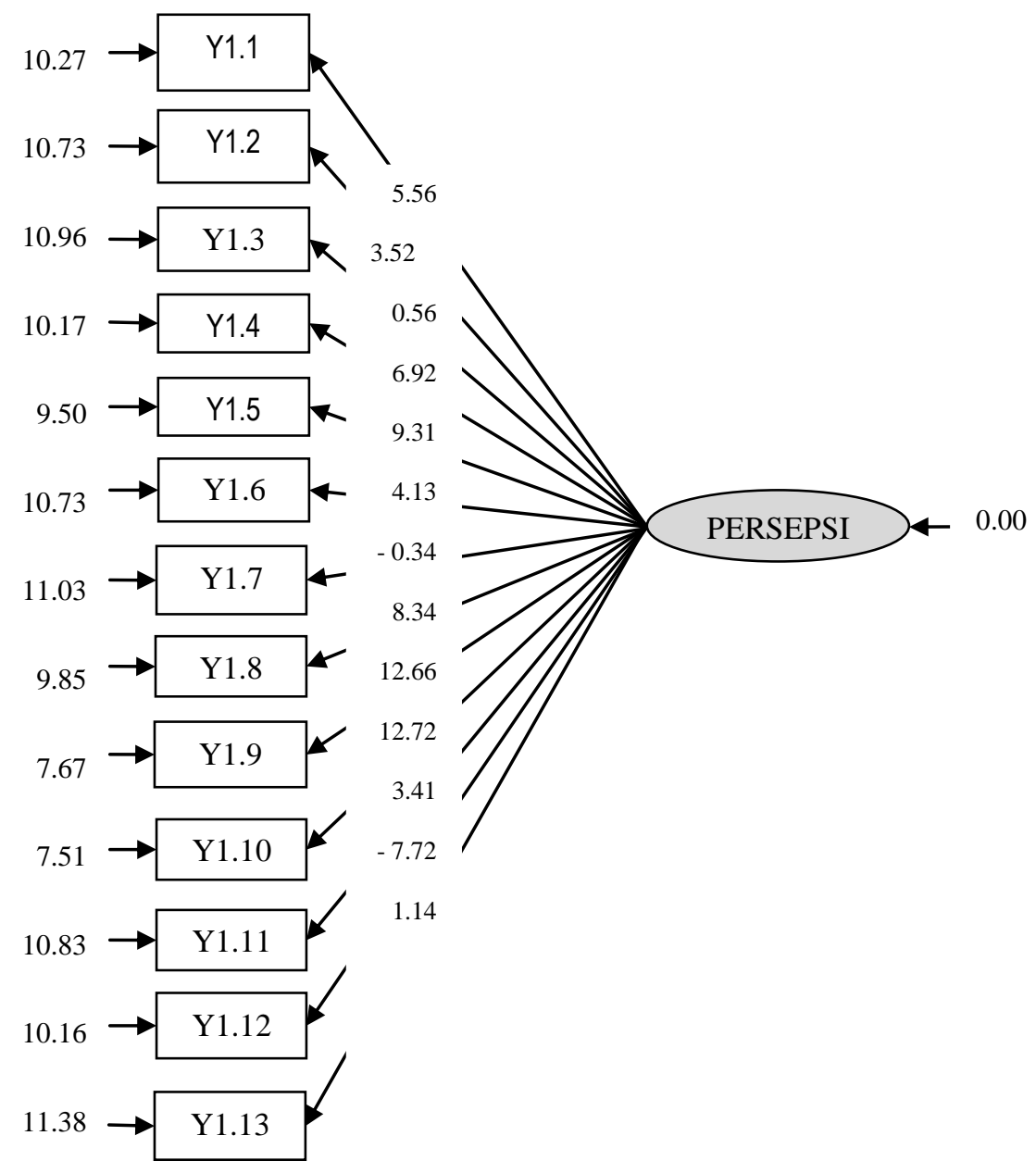

Chi-Square $=78.01, d f=44, P$-value $=0.00120, R M S E A=0,057$

Gambar 1. Statistik $t$-hitung parameter antara konstruk persepsi dan peubah indikatornya

Hasil pengujian data sampel menggunakan Kruskal-Wallis Test menunjukkan bahwa indikator karakteristik eksternal peternak sapi potong secara umum berbeda secara nyata, kecuali ketersediaan informasi IB untuk diakses tidak berbeda secara nyata antar lokasi penelitian.

\section{Persepsi peternak sapi potong terhadap IB}

Persepsi peternak sapi potong terhadap IB adalah pemberian arti/makna yang diberikan berdasarkan proses pengamatan ataupun pengalaman dalam diri peternak terhadap IB dalam pernyataan setuju atau tidak setuju. Persepsi peternak sapi potong terhadap inovasi IB (PERSEPSI) mencakup aspek-aspek teknis, sosial budaya, ekonomi dan kebijakan pemerintah di bidang perbibitan sapi potong.
Persepsi yang benar terhadap hal-hal di atas sangat penting kaitannya dalam penerapan IB terutama dikaitkan dengan tujuan kebijakan perbibitan. Dari aspek teknis, yaitu jenis sapi bibit (Y1.1), tanda-tanda fisik sapi bibit (Y1.2), tujuan pembibitan/IB (Y1.3), pelayanan inseminator (Y1.4) dan tanda-tanda sapi berahi (Y1.5). Aspek sosial-budaya meliputi norma sistem sosial (Y1.6), kelembagaan peternak sapi (Y1.7) dan struktur sosial (Y1.8). Aspek ekonomi meliputi peningkatan produksi hasil IB (Y1.9) dan keuntungan relatif (Y1.10). Sedangkan aspek kebijakan mencakup persilangan (Y1.11), pemurnian (Y1.12) dan campuran (silang dan pemurnian) (Y1.13). Persepsi peternak terhadap IB ditunjukkan dalam pernyataan (1) sangat tidak setuju, (2) tidak setuju, (3) ragu-ragu, (4) setu- 
Tabel 3. Perbandingan koefisien bobot faktor peubah persepsi sebelum dan sesudah perbaikan

\begin{tabular}{|c|c|c|c|c|}
\hline \multirow[b]{2}{*}{ Indikator } & \multirow[b]{2}{*}{$t$-statistik*) } & \multicolumn{2}{|c|}{ Faktor loading } & \multirow[b]{2}{*}{ Keterangan } \\
\hline & & Awal & Perbaikan & \\
\hline Y1.1. (jenis sapi bibit) & 6,56 & 0,46 & 0,45 & \multirow{13}{*}{$\begin{array}{c}\text { Konstruk persepsi } \\
\text { reliabel dengan indikator } \\
\text { Y1.5, Y1.9 dan Y1.10 di } \\
\text { mana koefisien } \mathrm{VE}=0,51\end{array}$} \\
\hline Y1.2 (tanda fisik sapi bibit) & 3,52 & 0,25 & 0,24 & \\
\hline Y1.3 (tujuan pembibitan) & 0,56 & 0,04 & & \\
\hline Y1.4 (pelayanan inseminator) & 6,92 & 0,47 & 0,45 & \\
\hline Y1.5 (tanda sapi induk berahi) & 9,31 & 0,60 & 0,56 & \\
\hline Y1.6 (norma sistem sosial) & 4,13 & 0,29 & 0,28 & \\
\hline Y1.7 (kelembagaan peternak) & $-0,34$ & 0,03 & & \\
\hline Y1.8 (struktur sosial) & 8,34 & 0,55 & 0,57 & \\
\hline Y1.9 (peningkatan produksi hasil IB) & 12,66 & 0,76 & 0,78 & \\
\hline Y1.10(keuntungan relatif) & 12,72 & 0,77 & 0,74 & \\
\hline Y1.11(kebijakan persilangan) & 3,41 & 0,24 & 0,25 & \\
\hline Y1.12(kebijakan pemurnian) & $-7,72$ & $-0,51$ & $-0,53$ & \\
\hline Y1.13(kebijakan campuran) & 1,14 & 0,09 & & \\
\hline
\end{tabular}

ju dan (5) sangat setuju terhadap pernyataan tentang dimensi dari aspek-aspek di atas. Hubungan antara konstruk persepsi dengan indikator-indikatornya dapat dilihat pada Gambar 1.

Nilai $t$-statistik menunjukkan hubungan antara indikator dan konstruk latennya. Apabila nilai $t$-hitung ini lebih kecil dari 1,96 maka pengukuran konstruk oleh indikator tersebut tidak signifikan (nyata pada $\alpha=$ 0,05). Beberapa indikator yang tidak signifikan terhadap konstruk persepsi adalah tujuan
pembibitan/IB (Y1.3), kelembagaan peternak sapi (Y1.7) dan kebijakan campuran (pemurnian dan silang) (Y1.13). Nilai $t$-hitung dan koefisien bobot faktor untuk masing-masing indikator dapat dilihat padaTabel 4.

Evaluasi terhadap reliabilitas konstruk persepsi berdasarkan seluruh indikatornya menghasilkan koefisien $\mathrm{VE}=0,21$. Jika mendasarkan hanya pada indikator yang secara statistik signifikan (hasil perbaikan), maka diperoleh koefisien $\mathrm{VE}=0,27$. Hal ini belum memenuhi persyaratan tidak kurang dari 0,50. Oleh karena itu, dilakukan

Tabel 4. Hasil analisis Kruskal-Wallis test persepsi peternak

\begin{tabular}{|c|c|c|c|c|}
\hline \multirow[b]{2}{*}{ Persepsi terhadap IB dari aspek: } & \multicolumn{3}{|c|}{ Hasil test } & \multirow[b]{2}{*}{ Keterangan } \\
\hline & Chi-Square & $d f$ & Asymp. Sig & \\
\hline \multicolumn{5}{|l|}{ Teknis } \\
\hline - Jenis sapi bibit & 145,925 & 2 & 0,000 & \\
\hline - Tanda-tanda fisik sapi bibit & 5,852 & 2 & 0,054 & Tidak berbeda \\
\hline - Tujuan pembibitan/IB & 30,473 & 2 & 0,000 & \\
\hline - Pelayanan inseminator & 4,329 & 2 & 0,115 & Tidak berbeda \\
\hline - Tanda-tanda sapi induk berahi & 14,451 & 2 & 0,001 & \\
\hline \multicolumn{5}{|l|}{ Sosial-budaya } \\
\hline - Norma sistem sosial & 72,361 & 2 & 0,000 & \\
\hline - Kelembagaan peternak sapi & 75,568 & 2 & 0,000 & \\
\hline - Struktur sosial & 66,333 & 2 & 0,000 & \\
\hline \multicolumn{5}{|l|}{ Ekonomi } \\
\hline - Peningkatan produksi hasil IB & 95,296 & 2 & 0,000 & \\
\hline - Keuntungan relatif & 74,456 & 2 & 0,000 & \\
\hline \multicolumn{5}{|l|}{ Kebijakan } \\
\hline - Persilangan & 47,130 & 2 & 0,000 & \\
\hline - Pemurnian & 84,452 & 2 & 0,000 & \\
\hline - Persilangan dan pemurnian (campuran) & 48,676 & 2 & 0,000 & \\
\hline
\end{tabular}

Tabel Chi-Square untuk $\mathrm{df}=2$ dan tingkat signifikansi $(\alpha)=5 \%$ maka didapat statistik tabel $=5,991$ 
Tabel 5. Hasil uji Mann Whitney $U$ terhadap persepsi peternak sapi potong antar lokasi penelitian

\begin{tabular}{|lccc|}
\hline \multirow{2}{*}{$\begin{array}{c}\text { Indikator persepsi peternak } \\
\text { tentang IB }\end{array}$} & \multicolumn{3}{c|}{ Nilai probabilitas dari hasil statistik-hitung*) } \\
\cline { 2 - 4 } & $\begin{array}{c}\text { Bangkalan dan } \\
\text { Lamongan }\end{array}$ & $\begin{array}{c}\text { Bangkalan dan } \\
\text { Tabanan }\end{array}$ & $\begin{array}{c}\text { Lamongan dan } \\
\text { Tabanan }\end{array}$ \\
\hline Y1.1 (jenis sapi bibit) & 0,000 & 0,000 & 0,000 \\
\hline Y1.2 (tanda-tanda fisik sapi bibit) & 0,030 & 0,043 & 0,940 \\
\hline Y1.3 (tujuan pembibitan/IB) & 0,000 & 0,000 & 0,103 \\
\hline Y1.4 (pelayanan inseminator) & 0,057 & 0,293 & 0,177 \\
\hline Y1.5 (tanda-tanda sapi betina berahi) & 0,001 & 0,510 & 0,001 \\
\hline Y1.6 (norma sistem sosial) & 0,000 & 0,354 & 0,000 \\
\hline Y1.7 (kelembagaan peternak sapi & 0,000 & 0,046 & 0,000 \\
\hline Y1.8 (struktur sosial) & 0,000 & 0,000 & 0,536 \\
\hline Y1.9 (peningkatan produksi sapi hasil IB) & 0,000 & 0,000 & 0,001 \\
\hline Y1.10 (keuntungan relatif) & 0,000 & 0,000 & 0,001 \\
\hline Y1.11 (kebijakan persilangan) & 0,093 & 0,000 & 0,000 \\
\hline Y1.12 (kebijakan pemurnian) & 0,000 & 0,000 & 0,000 \\
\hline Y1.13 (kebijakan pemurnian dan silang) & 0,000 & 0,000 & 0,589 \\
\hline
\end{tabular}

*) Probability $=0,05$

pengedropan kembali terhadap beberapa indikator yang koefisien bobot faktor-nya kurang dari 0,40 (kecuali indikator tanda-tanda sapi berahi mempunyai bobot faktor 0,36 ), yaitu indikator jenis sapi bibit (Y1.1), tandatanda fisik sapi bibit (Y1.2), pelayanan inseminator (Y1.4), norma sistem sosial (Y1.6), struktur sosial (Y1.8), kebijakan persilangan (Y1.11) dan kebijakan pemurnian (Y1.12). Hasil evaluasi terhadap persepsi menghasilkan koefisien $\mathrm{VE}=0,51 \quad(>0,50)$. Dengan demikian, konstruk persepsi dinyatakan reliabel.

Berdasarkan tingkat kesalahan pengukurannya, beberapa indikator persepsi yang dominan sebagai pembentuk peubah persepsi adalah jenis bibit sapi $39 \%\left(\mathrm{R}^{2}=0,20\right)$, pelayanan inseminator $13 \%\left(\mathrm{R}^{2}=0,20\right)$, tanda sapi induk berahi $11 \%\left(\mathrm{R}^{2}=0,32\right)$, struktur sosial $20 \%\left(\mathrm{R}^{2}=0,32\right)$, peningkatan produksi hasil IB $7 \%\left(\mathrm{R}^{2}=0,61\right)$, keuntungan relatif $19 \%$ $\left(\mathrm{R}^{2}=0,54\right)$ dan kebijakan pemurnian $28 \%$ $\left(\mathrm{R}^{2}=0,28\right)$.

Untuk menguji apakah persepsi peternak sapi potong terhadap IB di ketiga lokasi penelitian tersebut sama atau berbeda, digunakan uji Kruskal-Wallis. Hipotesis untuk kasus ini adalah: $\mathrm{H}_{0}=$ persepsi ketiga peternak sapi potong di ketiga lokasi penelitian tidak berbeda secara signifikan. $\mathrm{H}_{1}=$ setidaknya persepsi peternak sapi potong di salah satu lokasi penelitan menunjukkan perbedaan yang signifikan tentang IB;

Hasil pengujian menunjukkan bahwa secara umum statistik hitung indikator persepsi lebih besar dari statistik tabel $(5,99)$, kecuali tanda-tanda sapi bibit (Y1.2) dan pelayanan inseminator (Y1.4), maka hipotesa yang menyatakan ada perbedaan yang nyata persepsi peternak sapi potong antar lokasi penelitian diterima, kecuali indikator tandatanda fisik sapi bibit dan pelayanan inseminator.

Untuk mengetahui lokasi penelitian mana yang berbeda, dilakukan pengujian dengan Mann Whitney U test, yaitu antara Kabupaten Bangkalan dan Lamongan, Bangkalan dan Tabanan serta Lamongan dan Tabanan. Di mana $\mathrm{H}_{0}$ : persepsi peternak sapi potong di kedua lokasi penelitian tidak berbeda secara signifikan; $\mathrm{H}_{1}=$ persepsi peternak sapi potong di kedua lokasi penelitian menunjukkan perbedaan yang signifikan tentang IB. Hasil uji Mann Whitney $U$ dapat dilihat pada Tabel 5.

Hasil pengujian statistik menunjukkan bahwa indikator persepsi peternak sapi potong tentang IB antara Kabupaten Bangkalan dan Lamongan secara umum menghasilkan probability lebih kecil dari 0,05 , maka $\mathrm{H}_{0}$ ditolak. Secara statistik terdapat perbedaan yang nyata persepsi peternak sapi potong tentang IB di kedua lokasi penelitian, kecuali indikator pe- 
layanan inseminator (Y1.4) dan kebijakan persilangan (Y1.11). Antara Kabupaten Bangkalan dan Tabanan secara umum juga menghasilkan probability lebih kecil dari 0,05, maka $\mathrm{H}_{0}$ ditolak. Artinya, terdapat perbedaan yang nyata persepsi peternak sapi potong tentang IB di kedua lokasi penelitian tersebut, kecuali indikator pelayanan inseminator (Y1.4), tanda-tanda sapi betina berahi (Y1.5) dan norma sistem sosial (Y1.6).Untuk Kabupaten Lamongan dan Tabanan secara umum juga menghasilkan probability lebih kecil dari 0,05, maka $\mathrm{H}_{0}$ ditolak. Berarti hipotesa penelitian yang menyatakan bahwa terdapat perbedaan yang nyata persepsi peternak sapi potong kedua lokasi penelitian tersebut diterima, kecuali indikator tanda-tanda fisik sapi bibit (Y1.2), tujuan pembibitan (Y1.3), pelayanan inseminator (Y1.4), struktur sosial (Y1.8) dan kebijakan pemurnian dan silang (Y1.13) menunjukkan tidak ada perbedaan yang nyata di kedua lokasi penelitian tersebut.

Terhadap indikator tanda-tanda fisik sapi bibit, pada dasarnya jenis sapi pejantan yang digunakan untuk menghasilkan semen, masing-masing jenis sapi mempunyai fenotipe (ciri-ciri fisik) yang berbeda. Setiap jenis sapi, mempunyai peminatnya sendiri dan sering merupakan bagian dari aspek sosial-budaya dari peternak yang memeliharanya. Namun demikian, ciri umum sapi bibit secara fisik harus mepunyai postur tubuh yang besar. Hasil penelitian menunjukkan bahwa $71,2 \%$ responden setidaknya setuju sapi bibit harus mempunyai postur tubuh yang besar, hanya $10,4 \%$ responden yang menyatakan tidak setuju. Sedangkan terhadap pernyataan sapi bibit harus mempunyai "tubuh yang ideal atau proporsional" sebanyak $84,6 \%$ menyatakan setuju dan sangat setuju, hanya $0,8 \%$ yang tidak setuju. Preferensi responden terhadap sapi bibit adalah sapi "yang mempunyai gumba (punuk) yang tinggi” sebanyak 41,2\% setuju dan sangat setuju, 31,7\% ragu-ragu, dan $27,2 \%$ tidak setuju. Tingkat persepsi yang tinggi ditunjukkan oleh persetujuaan responden terhadap pernyataan bahwa sapi bibit secara fisik harus mempunyai "kondisi yang bagus dan berat", yaitu 90,8\%; hanya $1,7 \%$ yang tidak setuju dan $7,5 \%$ yang ragu-ragu.
Hal-hal yang bersifat fisik (mudah dilihat) dan kondisi yang ideal inilah mungkin yang menyebabkan mengapa persepsi responden terhadap ciri-ciri fisik sapi bibit menunjukkan tidak ada perbedaan secara nyata antar lokasi penelitian.

Setidak-tidaknya ada tiga tujuan IB dalam konteks pembibitan, yaitu (1) pemurnian, (2) persilangan, baik untuk menghasilkan sapi jenis baru ataupun menghasilkan final stock dengan memanfaatkan faktor heterosis dan (3) konservasi. Persepsi responden terhadap upaya pemurnian sapi Bali dan pelestarian sapi $\mathrm{PO} /$ Putih menunjukkan sebanyak $42,9 \%$ setuju dan 5,4\% sangat setuju. Sebaliknya, sebanyak $16,7 \%$ responden menyatakan tidak setuju. Sementara, sebanyak 35,0\% menunjukkan sikap ragu-ragu. Dalam kasus persilangan untuk menghasilkan jenis sapi baru, responden sebanyak $62,1 \%$ setuju dan $13,8 \%$ sangat setuju. Hanya $6,7 \%$ responden tidak setuju dan $17,5 \%$ ragu-ragu. Hal ini juga didukung oleh persepsi peternak untuk (1) memperoleh sapi induk yang dapat dikembangbiakkan lebih lanjut, yaitu sebanyak $85 \%$ setuju dan sangat setuju. Hanya 1,3\% responden yang tidak setuju, dan 13,7\% ragu-ragu; (2) menghasilkan sapi induk yang lebih baik dari tetuanya, yaitu sebanyak $87,8 \%$ responden menyatakan setuju. Untuk tujuan menghasilkan sapi turunan akhir (final stock), sebanyak 54,2\% responden setuju. Sebanyak $15,4 \%$ responden tidak setuju dan $30,4 \%$ responden ragu-ragu. Terhadap tujuan lain yang lebih bersifat fungsional, seperti untuk menghasilkan sapi kerja, responden sebanyak $34,1 \%$ menyatakan tidak setuju, 30,4\% raguragu dan $35,4 \%$ menyatakan setuju. Sedangkan yang terkait dengan sapi turunan IB dalam penggunaannya untuk acara adat ataupun keagamaan, sebanyak $51,2 \%$ responden menyatakan setuju, 35\% responden raguragu dan $13,8 \%$ responden menyatakan tidak setuju. Hal yang menarik adalah ketika responden ditanyakan persepsinya tentang tujuan IB adalah untuk menghasilkan turunan yang harganya lebih mahal dibanding dengan sapi turunan hasil kawin alam, responden menyatakan $68,8 \%$ setuju dan $24,5 \%$ sangat 
setuju. Hanya $1,7 \%$ responden yang tidak setuju dan 5,0\% responden ragu-ragu.

Dalam pelayanan inseminator, dalam penelitian ini dilihat dari dua dimensi, yaitu kesiapan inseminator memberikan pelayanan IB kapanpun saat diminta dan pelayanan yang diberikan apakah sesuai dengan permintaan peternak, khususnya terhadap jenis semen dan nama pejantan yang diinginkan. Hasil penelitian menunjukkan bahwa dalam memberikan pelayanan IB, 97,5\% responden menyatakan inseminator selalu siap memberikan pelayanan IB kapanpun diminta. Selebihnya, 2,5\% responden menyatakan ragu-ragu. Begitu juga terhadap permintaan peternak tentang jenis sapi yang diminta, $80,4 \%$ responden memperoleh jenis sapi yang diinginkan. Sebanyak 19,2\% responden menunjukkan sikap ragu-ragu dan sebanyak $0,4 \%$ tidak setuju. Terhadap biaya pelayanan IB yang harus dibayar oleh peternak, sebanyak 93,3\% responden menilai sebanding (memadai) dengan hasil yang akan diperoleh. Dalam pemberian pelayanan IB, sebanyak $89,6 \%$ responden menyatakan bahwa inseminator juga sering melakukan penyuluhan ataupun memberikan pembinaan teknis kepada peternak. Hal ini tidak banyak dilakukan oleh inseminator di luar pemberian pelayanan IB. Tidak adanya perbedaan yang signifikan antar lokasi penelitian dalam kualitas pelayanan inseminator ini dapat dijelaskan bahwa pelayanan inseminator merupakan bagian dari sistem IB yang berlaku secara nasional. Kebijakan penerapan IB secara nasional dilengkapi dengan standar pelayanan teknis minimal yang harus dipenuhi oleh inseminator dalam memberikan pelayanan IB. Tidak adanya perbedaan yang signifikan tanda-tanda sapi bibit dan pelayanan inseminator di ketiga lokasi penelitian ini menunjukkan bahwa keduanya lebih mudah ditangkap secara inderawi dan lebih bermakna bagi peternak.

Salah satu pengetahuan yang harus dimiliki peternak dalam pelaksanaan IB adalah tanda-tanda sapi induk berahi (minta kawin). Hal ini penting karena "masa subur" sapi induk terjadi enam jam setelah tanda-tanda berahi tersebut muncul. Oleh karena itu peternak harus benar-benar mengenali tanda-tanda berahi tersebut dan segera melapor ke petugas IB (inseminator) agar sapinya dapat diinseminasi dalam waktu yang tepat sehingga dapat terjadi kebuntingan. Dari lima tandatanda sapi induk berahi yang sering digunakan, sebanyak $97,1 \%$ responden setidaknya setuju dengan "tanda kelamin induk mengeluarkan cairan." Untuk tanda berahi "3A (abang, abuh, angat)" dan "suka menaiki sapi lainnya," mempunyai nilai yang sama, yaitu masing-masing sebanyak $91,9 \%$ responden setuju. Persepsi keraguan ditunjukkan oleh $30,8 \%$ responden dan $25 \%$ responden berturut-turut untuk tanda-tanda berahi "sapi tampak gelisah" dan "sapi sering melenguh."

Hasil penelitian menunjukkan bahwa IB tidak bertentangan dengan adat dan kebiasaan masyarakat. Hal ini ditunjukkan dengan $71,3 \%$ dan $12,5 \%$ responden menyatakan setuju dan sangat setuju. Dari perspektif agama, sebanyak $74 \%$ dan $11,7 \%$ responden menyatakan setuju dan sangat setuju bahwa IB tidak bertentangan dengan syariat agama. Bahkan, sapi hasil IB dapat digunakan untuk kepentingan acara adat ataupun keagamaan, walaupun adanya pernyataan keragu-raguan responden sebanyak 20,4\%. Persepsi ini sangat kuat untuk peternak di Kabupaten Lamongan dan Kabupaten Tabanan. Sedangkan di Kabupaten Bangkalan masih terdapat persepsi yang ragu-ragu (antara setuju dan tidak setuju) terhadap penggunaan sapi hasil IB untuk keperluan acara keagamaan. Dari aspek struktur sosial, sebanyak 45,0\% responden menyatakan keragu-raguan bahwa telah terjadi perubahan tujuan dan sasaran kelompok. Dengan adanya IB, peternak tidak lagi memelihara sapi jantan sebagai pemacek, atau setidak-tidaknya telah banyak berkurang.

Pengertian kebijakan secara umum adalah apapun yang dipilih pemerintah untuk dilakukan ataupun tidak dilakukan (Dye 1976:1). Kebijakan pemerintah di bidang perbibitan melalui penerapan IB pada sapi potong mencakup kebijakan persilangan, pemurnian atau campuran. Pengertian campuran di sini adalah pemerintah "tidak mengatur" secara tegas apakah diarahkan ke persilangan ataupun pemurnian. Persepsi peternak terhadap aspek kebijakan pemerintah di bidang 
perbibitan secara statistik menunjukkan perbedaan yang nyata antar lokasi penelitian (Chi-Square hitung> dari 5,991). Dalam kasus persilangan, yaitu menyilangkan sapi lokal ataupun sapi asli Indonesia dengan sapi impor yang umumnya didominasi sapi jenis Limousin, Simental, Brahman dan Brangus, 72,9\% responden setuju bahwa IB pada sapi potong memberikan keuntungan pada peternak. Bahkan, sebanyak $74,6 \%$ responden setuju bahwa perkawinan silang pada sapi potong dapat menyejahterahkan peternak. Terhadap semua pertanyaan berkaitan dengan kawin silang tersebut di atas, hanya 4,6\% responden yang menyatakan tidak setuju. Dalam hal pemurnian, persepsi peternak yang setuju tidak setinggi pada persilangan. Hanya $53,4 \%$ responden yang setuju bahwa pemurnian pada ternak sapi potong dapat memberikan keuntungan peternak, khususnya di Kabupaten Tabanan dan Kabupaten Bangkalan. Sebanyak $29,7 \%$ responden ragu-ragu dan sebanyak $18,8 \%$ responden tidak setuju. Begitu juga terhadap pertanyaan apakah dengan kebijakan pemurnian ini dapat menyejahterahkan peternak, hanya $48,7 \%$ yang menyatakan setuju, $33,8 \%$ ragu-ragu dan sebanyak 17,5\% tidak setuju. Terhadap pertanyaan apakah kebijakan pemurnian pada sapi potong sebaiknya diteruskan untuk melestarikan plasma nutfah ternak asli atau lokal, hanya $41,7 \%$ responden yang menyatakan setuju, sebanyak $45,8 \%$ menyatakan ragu-ragu dan $12,5 \%$ responden tidak setuju. Apakah kebijakan pemurnian pada sapi potong sesuai dengan keinginan peternak? Terhadap pertanyaan ini, hanya $38,7 \%$ responden menyatakan setuju, $42,1 \%$ responden menyatakan ragu-ragu dan sebanyak 19,2\% menyatakan tidak setuju. Untuk kasus campuran, antara yang setuju, ragu-ragu dan tidak setuju, pernyataan responden menunjukkan relatif menyebar secara merata. Terhadap pertanyaan apakah tanpa ada kebijakan persilangan atau pemurnian pada sapi potong (peternak bebas melakukan) akan memberikan keuntungan peternak? Sebanyak $43 \%$ menyatakan setuju, sebanyak $28,6 \%$ ragu-ragu dan $28,4 \%$ menyatakan tidak setuju. Begitu juga terhadap kemungkinan menyejahterahkan peternak, sebanyak $33,7 \%$ responden menyatakan setuju, sebanyak 30,8\% menyatakan tidak setuju dan sebanyak 29,5\% menyatakan ragu-ragu. Satu hal yang menarik adalah ketika dinyatakan apakah Pemerintah tidak perlu mengatur perkawinan ternak pada sapi potong?. Sebanyak $46,7 \%$ responden menyatakan tidak setuju, 22,8\% responden menyatakan ragu-ragu dan hanya $30,5 \%$ responden yang menyatakan setuju. Apakah kebijakan pemerintah untuk tidak mengatur perkawinan pada sapi potong sesuai dengan keinginan peternak? Sebanyak 39,6\% responden menyatakan setuju, 29,6\% ragu-ragu dan sebanyak $30,8 \%$ menyatakan tidak setuju.

\section{Kesimpulan}

Indikator yang signifikan dalam konstruk persepsi peternak sapi potong tentang IB adalah jenis sapi bibit, tanda-tanda fisik sapi bibit, pelayanan inseminator, tanda-tanda sapi berahi, norma sistem sosial, struktur sosial, peningkatan produksi hasil, keuntungan relative, kebijakan persilangan dan pemurnian. Adapun faktor tujuan pembibitan/IB, kelembagaan peternak sapi dan kebijakan campuran (pemurnian dan silang) secara statistik tidak signifikan.

Faktor yang dominan sebagai pembentuk konstruk persepsi peternak sapi potong tentang IB secara berurutan adalah peningkatan produksi hasil IB, keuntungan relatif, tanda sapi induk berahi, struktur sosial, kebijakan pemurnian, jenis bibit sapi dan pelayanan inseminator.

Secara umum persepsi peternak sapi potong tentang IB menunjukkan perbedaan yang nyata antar lokasi penelitian, kecuali (a) indikator pelayanan inseminator dan kebijakan persilangan di antara Kabupaten Bangkalan dan Lamongan, (b) indikator pelayanan inseminator, tanda-tanda sapi betina berahi dan norma sistem sosial di antara Kabupaten Bangkalan dan Tabanan dan (c) indikator tanda-tanda fisik sapi bibit, tujuan pembibitan, pelayanan inseminator, struktur sosial dan kebijakan pemurnian dan silang di antara Kabupaten Lamongan dan Tabanan, menunjukkan tidak ada perbedaan yang nyata. 
Jurnal Penyuluhan, Maret 2012 Vol. 8 No. 1

\section{Daftar Pustaka}

[BIB] Balai Inseminasi Buatan Lembang, 2001. Kiprah balai inseminasi buatan Lembang dalam pembangunan peternakan. Balai Inseminasi Buatan Lembang, Direktorat Jenderal Bina Produksi Peternakan, Departemen Pertanian, Bandung.

Foote RH. 1981. Animal industries heavily dependent on reproductive technology: The artificial insemination industry in new technologies in animal breeding. Editor Benjamin G. Brackett, George E. Seidel and Sarah M. Seidel. Academic Press. Pp. 13-39.

Dye TR. 1976. Policy analysis: What government do, why they do, and what difference it makes. The University of Alabama Press, Alabama.

Gordon IR. 2004. Reproductive technologies in farm animals. CABI Publishing, Oxfordshire, United Kingdom.

Kuntowijoyo. 2003. Radikalisasi petani: Esaiesai sejarah. Bentang Budaya, Yogyakarta.
Lionberger HF, Gwin H. 1982. Communication strategies: A guide for agricultural change agents. The Interstate Printers \& Publisher Inc., Illinois.

Nasution Z. 2002. Komunikasi pembangunan: Pengenalan teori dan penerapannya. Edisi Revisi. RajaGrafindo Persada, Jakarta.

Rogers EM. 2003. Diffusion of Innovations. $5^{\text {th }}$ Edition. The Free Press, New York.

Rogers EM, Shomaker FF. 1995. Communication of innovation: across cultural approach. Revised Ed. The Free Press. A Division of Macmillan Pub. Co Inc, New York.

Skjervold H. 1982. The results of 20 years selection for production in cattle, sheep and pigs: which way now? In, Future development in genetic improvement of animals. Ed. by J.S.F. Barker, Keith Hammond and A.E. McClitock. Academic Press, Sydney. Pp. 3-14.

van den Ban AW, Hawkins HS. 1999. Penyuluhan pertanian [terjemahan, Agricultural extensión]. Kanisius, Yogyakarta. 